\title{
TRUSTED DATA COMMUNICATION AND SECURITY ISSUES IN GNSS NETWORK OF TURKEY
}

\author{
Sedat BAKICI, Bilal ERKEK, Volkan MANTI and Alper ALTEKIN \\ Mapping Department of General Directorate of Land Registry and Cadastre, 06550 Cankaya, ANKARA, TURKEY \\ sbakici@tkgm.gov.tr, berkek@tkgm.gov.tr, aaltekin@tkgm.gov.tr,vmanti@tkgm.gov.tr
}

KEY WORDS: Geoinformation/GI, GNSS/GPS, Data Communication, RTK GNSS Network, CORS-Tr, Data Security, Cyber Security

\begin{abstract}
There are three main activities of General Directorate of Land Registry and Cadastre. These are Mapping, Land Registry and Cadastre. Geomatic Department is responsible for mapping activities. The most important projects like TUSAGA-Aktif (CORS-Tr), Metadata Geoportal, Orthophoto Production and orthophoto web services and preparation of Turkish NSDI Feasibility Report have been conducted and completed by this department's specialists since 2005 .
\end{abstract}

TUSAGA-Aktif (CORS-Tr) System, serves location information at cm level accuracy in Turkey and TR Nortern Cyprus in few seconds, where adequate numbers of GNSS satellites are observed and communication possibilities are present. No ground control points and benchmarks are necessary. There are 146 permanent GNSS stations within the CORS-Tr System. Station data are transferred online to the main control center located in the Mapping Department of the General Directorate of Land Registry and Cadastre and to the control center located in the General Command of Mapping. Currently CORS-Tr has more than 9000 users. Most of them are private companies working for governmental organization.

Providing data communication between control center and both GNSS station and users via trusted and good substructure is important. Additionally, protection of the system and data against cyber attacks from domestic and foreign sources is important. This paper focuses on data communication and security issues of GNSS network named TUSAGA-Aktif.

\section{INTRODUCTION}

A CORS is a Continuously Operating Reference Station. CORS can take the place of a traditional base station used in differential GNSS positing. They can give an instant position to an accuracy of a few $\mathrm{cm}$ and are used in many industries including Precision Agriculture, Construction, Mining, Surveying and in Scientific Research [1].

Continuously Operating Reference Stations GNSS Network Project called CORS-Tr (TUSAGA-Aktif in Turkish) has begun in 2006 as a research and development project of The Scientific and Technological Research Council of Turkey (TUBITAK) by supporting financial side, Istanbul Kultur University (IKU) as a project implementer and The General Directorate of Land Registry and Cadastre (TKGM) and General Command of Mapping (HGK) including as joint customers. CORS-Tr project completed in 2009 and operated by TKGM and HGK collectively. Until 15 June 2011, it was operated free of charge for test purposes. Since then it has been operating as a paid service and price is determined by Inter Ministries Mapping Coordination and Planning Committee (BHIKPK) and confirmed by both Ministers who are Environment and Urbanization Minister and Defense Minister.
TUSAGA-Aktif (CORS-Tr) System, serves location information by $\mathrm{cm}$ level accuracy in Turkey and TR Nortern Cyprus in few seconds, where adequate numbers of GNSS satellites are observed and communication possibilities are present. No ground control points and benchmarks are necessary. CORS-Tr System includes 146 permanent GNSS stations. Station data is transferred online to the main control center located in the Mapping Department of the General Directorate of Land Registry and Cadastre and the second control center located in the General Command of Mapping.

Today CORS-Tr System has more than 9000 individual users which can be grouped as Land Registry and Cadastral Offices, Governmental institutions, Licensed Surveyors, Universities and Private Companies. All user have chance to get good services from Geomatic Department via detailed web page, SMS and email message. More over call center (444) support is available in case of any problems on the field for $24 / 7$.

This paper presents trusted data communication infrastructure and security issues of CORS-Tr system in Geomatic Departments. 


\section{CORS-TrDATA COMMUNICATION}

A GNSS network consists of several GNSS stations interconnected by reliable communications to enable real time computations and control. Each station has a cabinet which contains a receiver, an antenna, communication devices, small data storage, power supply, accumulator and so on. In most cases a computer is installed additionally for data transmission and control. It also contains a user interface which is required to configure and maintain the network. This may be realized remotely for example by radio communication, mobile phones or via internet connection.

In Turkey Turk Telekom Backbone for CORS-Tr data communication is available. CORS-Tr system has VPN tunel between reference station and control center as primary data communication and $3 \mathrm{G}$ APN tunnel as secondery. User connections are supported by APN tunnel by all three GSM Operators in Turkey. And all RTK correction send to user via an APN tunnel. Data communication structure is shown in section 3.3 Networks topic (Figure 3).

\section{CORS-Tr SECURITY ISSUES}

Cybersecurity is the body of technologies, processes and practices designed to protect networks, computers, programs and data from attack, damage or unauthorized access. In a computing context, the term security implies cybersecurity. Elements of cybersecurity includes [2]:

- Application security

- Information security

- Network security

- Disaster recovery / business continuity planning

- End-user awareness and education.

\subsection{Applications}

In CORS-Tr system, we have Network RTK correction, networks DGPS correction, web online processing services and RINEX datas to provide our users. All applications are shown below.

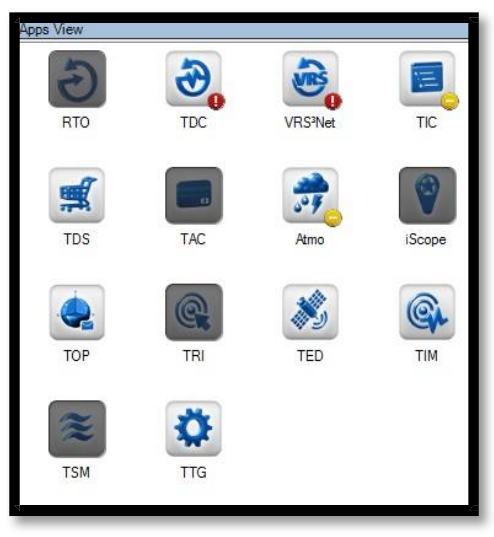

Figure 1.a: TUSAGA-Aktif applications

\begin{tabular}{|l|l|l|l|}
\hline \multicolumn{5}{|c|}{ CORS-Tr Main Applications } \\
\hline RTO & $\begin{array}{l}\text { Real Time } \\
\text { Output }\end{array}$ & İScope & $\begin{array}{l}\text { Realtime } \\
\text { Visualization }\end{array}$ \\
\hline TDC & $\begin{array}{l}\text { Dynamic } \\
\text { Control }\end{array}$ & TOP & Web Online Proces. \\
\hline VRSNet & Corrections & TRI & Rover Integrity \\
\hline TIC & $\begin{array}{l}\text { Instrum. } \\
\text { Config. }\end{array}$ & TED & $\begin{array}{l}\text { Ephemeris } \\
\text { Download. }\end{array}$ \\
\hline TDS & Data Shop & TIM & Integrity Manager \\
\hline TAC & Accounting & TSM & Streaming Manager \\
\hline Atmo & Atmos. App. & TTG & $\begin{array}{l}\text { Transformation } \\
\text { Mang. }\end{array}$ \\
\hline
\end{tabular}

Figure 1.b: TUSAGA-Aktif applications

\subsection{Information}

CORS-Tr system works with 3 SQL databases which are $\boldsymbol{T P P D B}$ contains the history of the system, TPPAccounting contains the accounting information such as user, subscriptions, sessions, etc. and TPPDBRoverIntergrity is a separate database for the rover integrity results. Additionally we have RINEX datas, control center camera records and callcenter recorded voices.

\begin{tabular}{|c|c|c|c|c|c|c|}
\hline $\begin{array}{l}\mathbf{N} \\
\mathbf{o}\end{array}$ & $\begin{array}{c}\text { Information } \\
\text { Type }\end{array}$ & $\begin{array}{l}\text { Resp. } \\
\text { Unit }\end{array}$ & $\begin{array}{c}\text { Backup } \\
\text { Period }\end{array}$ & Where & $\begin{array}{c}\text { Keeping } \\
\text { Duratio } \\
\text { n }\end{array}$ & $\begin{array}{c}\text { Time } \\
\text { Delive } \\
\text { r } \\
\text { to } \\
\text { Achiev } \\
\text { e }\end{array}$ \\
\hline $\begin{array}{l}\mathrm{Y} \\
1 \\
\end{array}$ & RINEX 1 Sec. & Geodesy & Weekly & Geodesy & 3 Month & -------- \\
\hline $\begin{array}{l}\mathrm{Y} \\
2\end{array}$ & $\begin{array}{l}\text { RINEX } 30 \\
\text { Sec. }\end{array}$ & Geodesy & Monthly & Geodesy & 1 Year & $\begin{array}{c}\text { End of } \\
\text { the } \\
\text { Year }\end{array}$ \\
\hline $\begin{array}{l}\mathrm{Y} \\
3\end{array}$ & $\begin{array}{c}\text { Database } \\
\text { Logs }\end{array}$ & Geodesy & Monthly & Geodesy & Endless & $\begin{array}{c}\begin{array}{c}\text { End of } \\
\text { the }\end{array} \\
\text { Year }\end{array}$ \\
\hline $\begin{array}{l}\mathrm{Y} \\
4\end{array}$ & $\begin{array}{l}\text { Control } \\
\text { Center } \\
\text { Camera } \\
\text { Records } \\
\end{array}$ & Geodesy & Monthly & Geodesy & 6 Month & --- \\
\hline $\begin{array}{l}\mathrm{Y} \\
5\end{array}$ & $\begin{array}{c}\text { Callcenter } \\
\text { Recorded } \\
\text { Voice } \\
\end{array}$ & $\begin{array}{l}\text { Data } \\
\text { Mang. }\end{array}$ & Monthly & Geodesy & 1 Year & - \\
\hline $\begin{array}{l}\mathbf{N} \\
\mathbf{o}\end{array}$ & $\begin{array}{c}\text { Informatio } \\
\text { n Type }\end{array}$ & $\begin{array}{l}\text { Resp. } \\
\text { Unit }\end{array}$ & $\begin{array}{c}\text { Achieving } \\
\text { Period }\end{array}$ & Where & $\begin{array}{c}\text { Keeping } \\
\text { Duratio } \\
\text { n }\end{array}$ & \\
\hline $\begin{array}{l}\mathrm{A} \\
1 \\
\end{array}$ & $\begin{array}{l}\text { RINEX } 30 \\
\text { Sec. }\end{array}$ & $\begin{array}{c}\text { Data } \\
\text { Mang. }\end{array}$ & Yearly & $\begin{array}{l}\text { Data } \\
\text { Mang. }\end{array}$ & 10 Year & \\
\hline $\begin{array}{l}\text { A } \\
2\end{array}$ & $\begin{array}{c}\text { Database } \\
\text { Logs }\end{array}$ & $\begin{array}{l}\text { Data } \\
\text { Mang. }\end{array}$ & Yearly & $\begin{array}{l}\text { Data } \\
\text { Mang. }\end{array}$ & Endless & \\
\hline
\end{tabular}

Figure 2-TUSAGA-Aktif Information to be backed up and to be archieved

\subsection{Networks}

We have two different networks in Geomatic Department. One of the network is CORS-Tr control center network, called 
METRO. Other is General Directorate of Land Registry and Cadastre (GDLRC) wide area network, called TAKBIS. TAKBIS network is under the responsibility of IT department of GDLRC. COSR-Tr network is an independent and special network. There is no connection or relation to TAKBIS network.

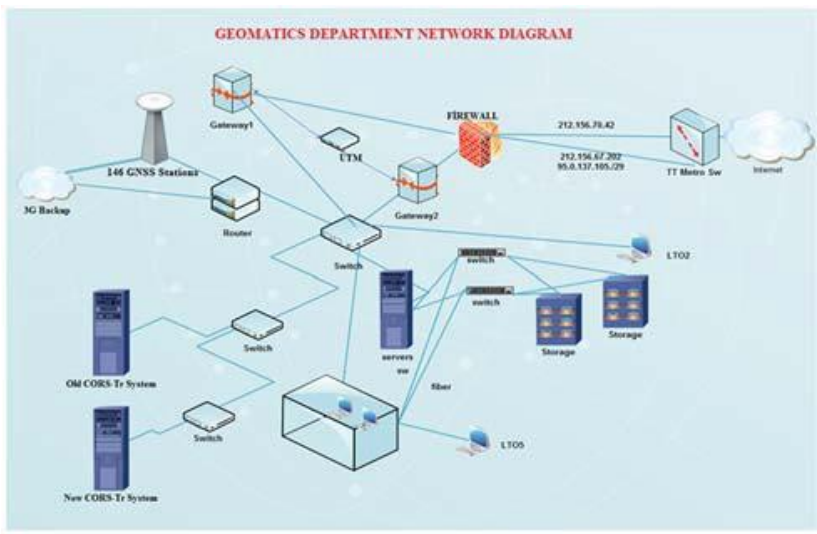

Figure 3- Geomatic Department Network Design

\subsection{Our Experience and Business continuity planning}

Of course CORS softwares including operating system and hardware, normally has their own firewall and some security issues with many applications. But we faced many problems since CORS-Tr established and these problems are briefly described below.

Lack of IT Personnel: Only Surveying Engineers and Surveying technicans were avaliable to operate CORS-Tr system, user membership and payment issues and to support users. There wasn't any IT staff to control system in case of a technical problem. Highly qualified geoinformatics personnel dealt with technical problems such as system freezing, communication bandwidth saturation or even exchange of broken hardisk.

DDOS Attacks: In summer season of year 2013 which mapping applications on the field by using CORS-Tr are very dense, we faced a very hard DDOS attack by an unknown source. DDOS attacks were continued for approximately 3 months, every day between 10 a.m. and 12 a.m.

Awareness of Internal Users: Internal system users who use computers that has virus, malware, trojan.etc. Internal users who used virus contaminated USB to connect system servers or unsafe remote desktop connection caused danger for the system. Unfortunately Institutional anti-virus system was unable to protect CORS-Tr system. Internal user's awareness on security issues should be increased.

Awareness of External Users: Some external users somehow adjusted their GNSS instrument settings to send more than five request in a second to connect CORS-Tr system. These requests interrupted other user connections and overloaded data communication bandwidth. Some external users shared their own password and user name with other users which cause conflict between the users. Another problem caused by external users is unnecessary attempts for connection. Although their term has finished many external users, try to connect to the system.

\section{IMPROVEMENTS}

Measures taken to establish trusted service in CORS-Tr system usage in terms of security requirements after experienced problems are:

- One specialised Computer Engineer and a specialised Electric and Electronic Engineer to operate COSR-Tr technical side were employed.

- UTM security device purchased for prevention from DDOS attacks. No DDOS attack detected since 2013.

- Directive about personal computer maintenance including software related security risks issued. Then data back-up and archiving directive with our employees in Geomatic Deparment issued.

- GNSS reference station data and information are stored in an SQL database. User information and activity log data are stored in another SQL database. These two databases and other related data have been started to be backed up ever day regularly according to department directive.

- Data comunication bandwidth enlarged from $20 \mathrm{~GB}$ to $50 \mathrm{~GB}$ after the realisation of unexpected external user dense connection activity.

- VPN tunnel established between reference station and control center as primary data communiciation and a 3G APN tunnel as secondary. Reference stations data storage capacity increased.

- Current software updated to latest version including required moduls such as Realtime Visualization, Atmosphere, Transformation Generator and Online Web Processing.

- New hardware provided according to updated software requirements.

- Main applications like Network RTK correction, networks DGPS correction and provision of RINEX data to the our users and SQL databases are protected by extra security software for cyber attacks.

- In CORS-Tr network, servers and end points are protected by a software from inside and outside cyber attacks.

- User awareness of CORS-Tr usage was increased by 444 call center, SMS message, Social Media and Local trainings. And also customer satisfaction are surveyed regularly.

\section{CONCLUSION}

At the beginning of TUSAGA-Aktif project we thought that project was considered geodesy related works only. Today we understood that TUSAGA-Aktif is not only a geodesic related work but also Information and Communication Technology work. 
As a result today CORS-Tr have trusted data communication infrastructure, protected information and services by updated software and hardware including security devices and has more powerful user support.

\section{REFERENCES}

[1] URL1:http://www.sage.unsw.edu.au/currentstudents/ug/projects /Gowans/Thesis/What_is_it.html

[2] URL2: http://whatis.techtarget.com/definition/cybersecurity 